\title{
Assessment of Manure Quality Prepared From Different Crop Residues Inoculated with Cellulolytic and Lignolytic Bacterial Isolates
}

\author{
T.M. Neethu ${ }^{1 *}$, K.G. Patel ${ }^{1}$, Singh Susheel ${ }^{1}$ and S. Sree Ganesh ${ }^{2}$ \\ ${ }^{1}$ Department of Soil Science and Agricultural Chemistry, NMCA, \\ Navsari Agricultural University, Navsari, Gujarat -396450, India \\ ${ }^{2}$ Department of Genetics and Plant Breeding, NMCA, Navsari Agricultural University, \\ Navsari, Gujarat -396450, India \\ *Corresponding author
}

\section{A B S T R A C T}

The best two each of cellulolytic $\left(\mathrm{C}_{1}\right.$ and $\left.\mathrm{C}_{2}\right)$ and lignolytic $\left(\mathrm{L}_{1}\right.$ and $\left.\mathrm{L}_{2}\right)$ out of 103 bacterial isolates isolated from compost, sea water, saline soil, black soil and forest soil samples were inoculated on sugarcane trash $\left(\mathrm{S}_{1}\right)$, paddy straw $\left(\mathrm{S}_{2}\right)$ and banana pseudostem $\left(\mathrm{S}_{3}\right)$ and incubated for $20,40,60,80,100,120$ days to record their impact on physico-chemical properties viz., loss in weight, $\mathrm{C}: \mathrm{N}$ ratio, cellulose and lignin content of the manures prepared from these substrates. This experiment was conducted using factorial CRD with two repetitions. The highest weight loss was observed in substrate $S_{3}$ (banana pseudostem),

Keywords

C: $\mathrm{N}$ ratio, Cellulolytic,

Lignolytic,

Half-life $\left(\mathrm{t}_{0.5}\right)$

Article Info

Accepted:

15 September 2017

Available Online:

10 November 2017 cellulolytic isolate $\mathrm{C}_{1}$ and lignolytic isolate $\mathrm{L}_{2}$ which was corroborated by the lower halflife values of manures i.e. $S_{3}$ ( 285 days), $C_{1}$ ( 345 days) and $L_{2}$ ( 255 days). Treatment effect on $\mathrm{C}: \mathrm{N}$ ratio was more or less similar to that observed in weight. The cellulose and lignin content was found lower in paddy straw $\left(\mathrm{S}_{2}\right)$ during all incubation periods as compared to other substrates. Although, a reduction in cellulose and lignin content of substrates was observed in cellulolytic isolates and lignolytic isolates in comparison to untreated control. However, a significant reduction on cellulose content was observed in all inoculated substrates but it absent in case of lignin. Confirmation of best treatment $\left(\mathrm{S}_{3}, \mathrm{C}_{1}\right.$, and $\left.\mathrm{L}_{2}\right)$ and to identify the factors that responsible for rate of degradation of crop residue, regression equation was worked out using almost all possible parameters. Among these, $\mathrm{W}=12.67+(0.24 \mathrm{C}: \mathrm{N}$ ratio $)+(0.12 \times \%$ Lignin $)-(0.06 \times \%$ Cellulose $)$ gave the highest $\mathrm{R}^{2}$ values $(0.59)$. The predicted weight under higher order interactions was calculated by using values of $\mathrm{C}: \mathrm{N}$ ratio, lignin and cellulose content in substrates. The minimum predicted and actual weight of 16.1 and $15.9 \mathrm{~g}$, respectively was recorded under the interaction $\mathrm{S}_{3} \times \mathrm{C}_{1} \times \mathrm{xL}_{2}$. The study reflects inoculation of agro-waste substrate with cellulolytic isolate $\mathrm{C}_{1}$ (identified as Bacillus licheniformis strain $\mathrm{C}_{1}$ ) and lignolytic isolate $\mathrm{L}_{2}$ (identified as Bacillus sp. strain $\mathrm{L}_{2}$ ) have pronounced impact on quality characteristic of manure such as $\mathrm{C}$ : $\mathrm{N}$ ratio, cellulose and lignin content as well as period required for preparation o manures.

\section{Introduction}

The mid- and late- $20^{\text {th }}$ century, green revolution achieved mainly due to introduction of high yielding varieties and chemical fertilizers. However, indiscriminate and injudicious use of chemical fertilizers and omission of organic manures in fertilizer 
management led to ecological and economical imbalance in agriculture which is reflected in drastic decline in quality of natural resources, crop productivity, fertilizer use efficiency soil health and increase in cost of production. Less use of organic manure in the country mainly due to (i) crop residue is an economic product and (ii) lengthy process of manure preparation. Major crop residues generated in the country are from cereals, cash crops, fruits and vegetables. These residues are in lignocellulolytic in nature and having high $\mathrm{C}$ : $\mathrm{N}$ ratio, takes relatively long time for decomposition. In recent years many researches are carried out to isolate the microbes having capability to degrade such crop residues in relatively shorter period. However, there is vide scope to explore and identify region specific microbial strains which have high crop residue decomposition capabilities. In India, over 500 million tonne (Mt) of agricultural residues is produced every year (Singh and Sidhu, 2014). Cereal crops (rice, wheat, maize, millets) contribute $70 \%$ of the total crop residues $(352 \mathrm{Mt})$ comprising $34 \%$ by rice. Sugarcane among the cash crop and banana among the fruit crops produce large quantity of crop residues. Crop residues of these crops are cellulolytic in nature and having wider $\mathrm{C}$ : $\mathrm{N}$ ratio. The composting of agricultural residues rich in lignocellulose like paddy straw, sugarcane trash, banana pseudostem generally takes 180 days or more to obtain good and mature compost (Singh and Nain, 2014). The period of decomposition can be reduced by the use of efficient ligno-cellulolytic microorganisms. Cellulose and lignin degrading microorganisms hasten the biodegradation of crop residues such as straw, leaves, trash etc. (Gaur, 1999). Through the synergistic action of microorganisms, complex organic compounds are degraded to smaller molecules, which can then be utilized by microbial cells (Golueke, 1991). Cellulolytic bacteria are ubiquitous in nature. Under congenial conditions bacteria can degrade cellulose and hence many bacterial strains are known to solubilize and modify the lignocellulosic structures extensively (Ball et al., 1989).Many of the bacterial strains are very efficient in lignin degradation also. Rice, sugarcane and banana are the major crops of South Gujarat and where residues of these crops are available in abundance throughout season. Therefore, an effort was made to Assess of manure quality prepared from different crop residues inoculated with cellulolytic and lignolytic bacterial isolates.

\section{Materials and Methods}

\section{Inoculation of isolated cellulolytic and lignolytic bacteria}

\section{Sample collection}

Sampling had done from compost, saline water, saline, black and forest soils. Compost prepared from NADEP method was collected from certified organic farm of Navsari Agricultural University (NAU), Navsari while saline water and saline soil samples were collected from Dandi farm, NAU, Navsari. However, soil samples from multiples sites were also collected from different farms of NAU, Navsari district having black soils and representing intensive farming region. The soil samples collected from Waghai (The Dangs district) represents forest soils.

\section{Isolation techniques}

Isolation of bacteria from the collected samples was done by serial dilution method (APHA, 1984).Primary screening of the bacterial isolates were performed on the basis of qualitative cellulase enzyme assay(Paterson and Bridge, 1994) and qualitative laccase assay (Thurston, 1994). However, the subsequent secondary screening was done by conducting quantitative 
estimation of cellulase (Miller, 1959), laccase (Wolfenden and Wilson, 1982), lignin peroxidase (Denise et al., 1996) and manganese peroxidase (Papinutti and Martinez, 2006).

Finally, the best two bacterial isolates each from cellulolytic and lignolyticclass were selected. These bacterial isolates were inoculated in substrates i.e. sugarcane trash, paddy straw and banana pseudostem.

\section{The substrates}

Sugarcane trash, rice straw and banana pseudostem were collected, dried, grinded and sieved with $5 \mathrm{~mm}$ sieve. Initial composition of substrate used in the experiment is as under:

\section{Substrate inoculation procedure}

The $25.5 \mathrm{~g}$ substrate was taken in tissue culture glass jars as per treatments were double sterilized by autoclave at $120^{\circ} \mathrm{C}$ and $15 \mathrm{lbs}$ pressure for 45 minutes. Then as per the treatment inoculums was added in bottle under laminar air flow chamber. All the bottles containing substrate were incubated for 120 days. Total 360 bottles were prepared (27 treatments, 3 controls, 2 repetitions and 6 periods) and incubated for 120 days under normal room condition. Sterile distilled water was added at the time of incubation and subsequently during incubation as per need under laminar air flow. Observations were recorded at 20 days interval i.e. 20, 40, 60, 80, 100 and 120 days on destructive way. The experiment was conducted using FCRD design with two repetitions.

\section{Weight}

Treatment wise weight was recorded at 20, 40, 60, 80, 100 and 120 days and reported in gram.

\section{$\mathrm{C}: \mathrm{N}$ ratio}

$\mathrm{C}: \mathrm{N}$ ratio was calculated by taking the ratio of $\mathrm{C}(\%)$ to total $\mathrm{N}(\%)$. The $\mathrm{C}(\%)$ was calculated by Walkley and Black method (Jackson, 1973) and N (\%) was determined by Micro Kjeldahl method (Jackson, 1973). Treatment wise $\mathrm{C}$ : $\mathrm{N}$ ratio was recorded at 20, $40,60,80,100$ and 120 days of incubation.

\section{Cellulose content (\%)}

Cellulose content from the samples was determined by adopting standard procedure as describe by Sadasivam and Manickam (1992).

\section{Lignin content (\%)}

Lignin content of substrate sample was extracted in $\mathrm{NaOH}$. The amount of lignin is calculated from the phenol values of the hot alkali extract as given by Stafford (1960). Treatment wise lignin content was recorded at 40, 80 and 120 days of incubation.

\section{Dry mass remaining}

The periodic percentage of dry mass, cellulose and $\mathrm{C}$ : $\mathrm{N}$ remaining (PR) was calculated using the following equation:

Percent remaining: $\left(\mathrm{W}_{\mathrm{t}} / \mathrm{W}_{0}\right) \times 100$

Where, $\mathrm{W}_{\mathrm{t}}=$ Weight remained after each sampling $(\mathrm{g})$ and, $\mathrm{W}_{0}=$ Initial weight $(\mathrm{g})$ which is potentially decomposable

\section{Half-life}

The regressions of $\ln \left(\mathrm{W}_{\mathrm{t}} / \mathrm{W}_{0}\right)$ over time were performed using exponential model $\left(\mathrm{W}_{\mathrm{t}}: \mathrm{W}_{0} \mathrm{e}^{-}\right.$ ${ }^{k t}$; where $\mathrm{W}_{0}$ : initial residue weight at time zero, $\mathrm{W}_{\mathrm{t}}=$ Residue remaining after a given time (t), t: time interval of sampling $k$ : Decomposition rate constant and, e: base of natural logarithms) in excel for calculation of 
$k$ and $\mathrm{R}^{2}$. Further, the time required for $50 \%$ $\left(\mathrm{t}_{0.5}\right)$ decay was calculated as $\mathrm{t}_{0.5}=0.693 / \mathrm{k}$ and reported.

\section{Regression equation}

To establish the regression equation and predicted weight, relationship between independent variables (xi) and dependent variable (y), the regression coefficients (bi) was worked out as per standard procedure using M. S. Excel and the linear prediction equation $\mathrm{Y}=\mathrm{a}+\mathrm{b}_{\mathrm{i}} \mathrm{X}_{\mathrm{i}}$ and coefficient of determination $\left(\mathrm{R}^{2}\right)$ was worked out.

\section{Statistical analysis}

The data pertaining to weight, cellulose, $\mathrm{C}: \mathrm{N}$ ratio, lignin, etc. were subjected to statistical analysis. The statistical analysis was carried out as per the methods described by Panse and Sukhatme (1967).

\section{Results and Discussion}

\section{Identification of bacteria}

Based on sequence homology bacteria were identified as $\mathrm{C}_{1}$ as Bacillus licheniformis strain $\mathrm{C}_{1}$ and $\mathrm{L}_{2}$ as Bacillus sp. strain $\mathrm{L}_{2}$. Sequences were submitted to GenBank for accession number.

\section{Weight}

The results (Table 1) reveals that at 120 days of incubation, sugarcane trash, paddy straw and banana pseudostem had lost 12.9, 15.7 and $27.5 \%$ of its initial mass, respectively. For vivid and better understanding, the rate of decomposition, decomposition rate constants $(k)$ and the days taken for $50 \%$ of residues to decompose $\left(\mathrm{t}_{0.5}\right)$ were also calculated and results are presented in Table 2. The half-life $\left(\mathrm{t}_{0.5}\right)$ values (i.e. the time required to lose half of initial mass) of the substrates were in the following order: banana pseudostem (285 days), paddy straw (459 days), sugarcane trash (576 days). Faster rate of decomposition in banana pseudostem might be due to narrower $\mathrm{C}: \mathrm{N}$ ratio of the residue. The results of present study are taking to those reported earlier by Pangga et al., (2000).

The higher weight loss of substrates to initial weight at 120 days was observed when substrates were inoculated with cellulolytic isolate $\mathrm{C}_{1}$ and lignolytic isolate $\mathrm{L}_{2}$. Higher weight loss and faster rate of decomposition of substrate in inoculation treatments of $\mathrm{C}_{1}$ and $L_{2}$ might be due to higher enzyme production by both of this inoculant.

Time taken for $50 \%$ of residues to decompose $\left(t_{0.5}\right)$ was higher in this experiment because the substrates used in present investigation were autoclaved prior to inoculation with two bacterial isolates. However, in natural decomposition process, numerous microbes (bacteria, fungi, actinomycetes etc.) were simultaneously acting upon the substrates which boost up and facilitate faster decomposition of the substrates (Table 4). These results are in conformity with the results of Becking (2006).

\section{$\mathrm{C}: \mathbf{N}$ ratio}

The C: $\mathrm{N}$ ratio of the substrates at 120 days of incubation is presented in the Table 1. Initial $\mathrm{C}: \mathrm{N}$ ratio of the substrates $\mathrm{S}_{1}$ (sugarcane trash), $S_{2}$ (paddy straw) and $S_{3}$ (banana pseudostem) was 42.01, 53.91 and 29.0, respectively. After 120 day's incubation, the $\mathrm{C}: \mathrm{N}$ ratio was gradually decreased and became 33.6, 40.2 and 24.7, respectively for sugarcane trash $\left(\mathrm{S}_{1}\right)$, paddy straw $\left(\mathrm{S}_{2}\right)$ and banana pseudostem $\left(\mathrm{S}_{3}\right)$. Initial and after 120 days of incubation sugarcane trash had the narrower $\mathrm{C}$ : $\mathrm{N}$ ratio. However, the rate of narrowing the $\mathrm{C}$ : $\mathrm{N}$ ratio was slower in banana pseudostem as compared to sugarcane 
trash and paddy straw. It is also evident from half-life result, time taken to reduce $50 \%$ of $\mathrm{C}$ : $\mathrm{N}$ ratio to initial was more in banana pseudostem (445days) followed by sugarcane trash (437 days) and paddy straw (287 days) (Table 2). Slower rate in narrowing the $\mathrm{C}: \mathrm{N}$ ratio in banana pseudostem might be due to more loss of $\mathrm{NH}_{3}$ from this substrate.

Cellulolytic isolate $\mathrm{C}_{1}$ reduced the $\mathrm{C}$ : $\mathrm{N}$ ratio of the substrates from 38.1 at 20 days to 28 at 120 days. Similarly, lignolytic isolate $\mathrm{L}_{2}$ brought about the $\mathrm{C}$ : $\mathrm{N}$ ratio of 28.5 (120 days) from 40.0 (20 days). Half-life of the substrates inoculated with cellulolytic isolate
$\mathrm{C}_{1}$ and lignolytic isolate $\mathrm{L}_{2}$ was calculated and presented in Table 2. Among the $\mathrm{C}_{1}$ and $\mathrm{C}_{2}$ lower half-life was observed in $\mathrm{C}_{1}$ (258 days) and among the $\mathrm{L}_{1}$ and $\mathrm{L}_{2}$, lower half-life was observed in $\mathrm{L}_{2}$ (255 days). The reasons given for more weight reduction under the treatments $\mathrm{C}_{1}$ and $\mathrm{L}_{2}$ are equally applicable here also. More weight of substrate under both of the inoculation treatments decreased by loss of $\mathrm{C}$ as $\mathrm{CO}_{2}$, the $\mathrm{N}$ gets concentrated therefore, narrow $\mathrm{C}$ : $\mathrm{N}$ ratio may be observed in these treatments of inoculation. The result of present study is in agreement with the findings of Das and Patel (2011).

Initial composition of substrate used in the experiment

\begin{tabular}{|l|c|c|c|}
\hline \multirow{2}{*}{ Parameters } & \multicolumn{3}{|c|}{ Substrate } \\
\cline { 2 - 4 } & Sugarcane trash & Paddy straw & Banana pseudostem \\
\hline C: N & 42.01 & 53.91 & 29.0 \\
\hline Lignin $(\%)$ & 22.01 & 4.26 & 20.60 \\
\hline Cellulose (\%) & 40.70 & 37.80 & 48.80 \\
\hline
\end{tabular}

Table.1 Effect of different treatments on weight (g), C: $\mathrm{N}$ ratio, cellulose (\%) and lignin (\%) content of substrates at 120 day

\begin{tabular}{|c|c|c|c|c|}
\hline Treatments & Weight (g) & C: $N$ ratio & Cellulose (\%) & Lignin (\%) \\
\hline \multicolumn{5}{|l|}{ Substrate (S) } \\
\hline $\mathrm{S}_{1}$ & 22.2 & 33.6 & 32.7 & 25.2 \\
\hline $\mathrm{S}_{2}$ & 21.2 & 40.2 & 32.2 & 5.0 \\
\hline $\mathrm{S}_{3}$ & 18.5 & 24.7 & 38.3 & 20.7 \\
\hline S. Em \pm & 0.05 & 0.14 & 1.2 & 0.48 \\
\hline C. D. at $5 \%$ & 0.13 & 0.40 & 3.5 & 1.41 \\
\hline \multicolumn{5}{|c|}{ Cellulolytic bacteria (C) } \\
\hline $\mathrm{C}_{0}$ & 21.4 & 37.6 & 39.0 & 17.0 \\
\hline $\mathrm{C}_{1}$ & 19.9 & 28.0 & 31.6 & 16.4 \\
\hline $\mathrm{C}_{2}$ & 20.7 & 32.9 & 32.5 & 17.4 \\
\hline S. Em \pm & 0.05 & 0.14 & 1.2 & 0.48 \\
\hline C. D. at $5 \%$ & 0.13 & 0.40 & 3.5 & NS \\
\hline \multicolumn{5}{|c|}{ Lignolytic bacteria (L) } \\
\hline $\mathrm{L}_{0}$ & 22.0 & 38.6 & 40.2 & 17.9 \\
\hline $\mathrm{L}_{1}$ & 20.0 & 31.4 & 32.6 & 16.9 \\
\hline $\mathrm{L}_{2}$ & 19.9 & 28.5 & 30.4 & 16.1 \\
\hline S. Em \pm & 0.05 & 0.05 & 1.2 & 0.48 \\
\hline C. D. at $5 \%$ & 0.13 & 0.13 & 3.5 & 1.41 \\
\hline
\end{tabular}


Table.2 Decomposition rate constant $(k)$ and half -life $\left(\mathrm{t}_{0.50}\right)$ of weight of substrates, $\mathrm{C}$ : $\mathrm{N}$ ratio and cellulose content in substrates

\begin{tabular}{|c|c|c|c|c|c|}
\hline \multirow{2}{*}{$\begin{array}{l}\text { Parameter } \\
\text { Weight }\end{array}$} & \multicolumn{2}{|c|}{ Treatments } & \multirow{2}{*}{$\begin{array}{c}\boldsymbol{k} \\
0.0012 \\
\end{array}$} & \multirow{2}{*}{$\frac{\mathbf{R}^{\mathbf{2}}}{0.92}$} & \multirow{2}{*}{$\begin{array}{c}\mathbf{t}_{\mathbf{0 . 5 0}} \\
576.36\end{array}$} \\
\hline & \multicolumn{2}{|c|}{\begin{tabular}{|l|l}
$\mathbf{S}$ & $\mathrm{S}_{1}$
\end{tabular}} & & & \\
\hline & & $\mathrm{S}_{2}$ & 0.0015 & 0.91 & 458.82 \\
\hline & & $\mathrm{S}_{3}$ & 0.0024 & 0.99 & 284.62 \\
\hline & \multirow[t]{2}{*}{$\mathbf{C}$} & $\mathrm{C}_{1}$ & 0.0020 & 0.99 & 345.09 \\
\hline & & $\mathrm{C}_{2}$ & 0.0017 & 0.95 & 409.38 \\
\hline & \multirow{2}{*}{$\mathbf{L}$} & $\mathrm{L}_{1}$ & 0.0019 & 0.97 & 354.80 \\
\hline & & $\mathrm{L}_{2}$ & 0.0019 & 0.89 & 354.86 \\
\hline \multirow[t]{7}{*}{ C: $\mathbf{N}$ ratio } & \multirow{3}{*}{$\mathbf{S}$} & $\mathrm{S}_{1}$ & 0.0016 & 0.94 & 436.50 \\
\hline & & $\mathrm{S}_{2}$ & 0.0024 & 0.94 & 286.72 \\
\hline & & $\mathrm{S}_{3}$ & 0.0016 & 0.99 & 444.79 \\
\hline & \multirow{2}{*}{$\mathbf{C}$} & $\mathrm{C}_{1}$ & 0.0027 & 0.99 & 258.19 \\
\hline & & $\mathrm{C}_{2}$ & 0.0014 & 0.88 & 506.63 \\
\hline & \multirow{2}{*}{$\mathbf{L}$} & $\mathrm{L}_{1}$ & 0.0025 & 0.98 & 271.31 \\
\hline & & $\mathrm{L}_{2}$ & 0.0027 & 0.96 & 254.94 \\
\hline \multirow[t]{7}{*}{ Cellulose } & \multirow[t]{3}{*}{$\mathbf{S}$} & $\mathrm{S}_{1}$ & 0.0023 & 0.79 & 303.65 \\
\hline & & $\mathrm{S}_{2}$ & 0.0018 & 1.00 & 393.80 \\
\hline & & $\mathrm{S}_{3}$ & 0.0025 & 1.00 & 274.52 \\
\hline & \multirow[t]{2}{*}{$\mathrm{C}$} & $\mathrm{C}_{1}$ & 0.0023 & 0.96 & 297.56 \\
\hline & & $\mathrm{C}_{2}$ & 0.0029 & 0.97 & 237.77 \\
\hline & \multirow[t]{2}{*}{$\mathbf{L}$} & $\mathrm{L}_{1}$ & 0.0020 & 0.79 & 297.70 \\
\hline & & $\mathrm{L}_{2}$ & 0.0030 & 1.00 & 233.60 \\
\hline
\end{tabular}

Table.3 Regression equation with different parameters

\begin{tabular}{|l|l|c|c|}
\hline Sr.No. & Regression equation & $\mathbf{R}^{\mathbf{2}}$ & F value \\
\hline 1 & W=29.25-7.24N & 0.44 & 0.00009 \\
\hline 2 & W=14.30+0.193 C: $\mathrm{N}$ & 0.50 & 0.00002 \\
\hline 3 & $\mathrm{~W}=20.685-0.003 \mathrm{~L}$ & -0.04 & 0.96475 \\
\hline 4 & $\mathrm{~W}=19.30+0.04 \mathrm{CL}$ & -0.03 & 0.61644 \\
\hline 5 & $\mathrm{~W}=11.34+0.23 \mathrm{C}: \mathrm{N}+0.10 \mathrm{~L}$ & 0.58 & 0.00001 \\
\hline 6 & W=12.67+0.24 C: $\mathbf{N + 0 . 1 2} \mathbf{L - 0 . 0 6} \mathbf{C L}$ & $\mathbf{0 . 5 9}$ & $\mathbf{0 . 0 0 0 0 1}$ \\
\hline
\end{tabular}

$<0.05$ : Significant, $<0.01$ : Highly significant,

W: Weight, C: Carbon, N: Nitrogen, L: Lignin, CL: Cellulose, P: Phosphorus

Table.4 Weight and biochemical changes under natural decomposition at 120 days of incubation

\begin{tabular}{|l|l|l|l|}
\hline \multirow{2}{*}{ Parameters } & \multicolumn{3}{|l|}{ Substrate } \\
\cline { 2 - 4 } & Sugarcane trash & Paddy straw & Banana pseudostem \\
\hline Weight $(\mathrm{g})$ & 11.5 & 10.5 & 10.0 \\
\hline Lignin $(\%)$ & 15.0 & 3.48 & 13.2 \\
\hline Cellulose (\%) & 18.9 & 17.9 & 22.7 \\
\hline C: $\mathrm{N}$ & 16.4 & 21.4 & 13.7 \\
\hline
\end{tabular}


Table.5 Predicted and original weight of the substrate inoculated with cellulytic and lignolytic bacteria at 120 days of incubation

\begin{tabular}{|c|c|c|c|}
\hline Sr.No. & Parameters & Predicted weight (g) & Original weight (g) \\
\hline 1 & $\mathrm{~S}_{1} \mathrm{C}_{1} \mathrm{~L}_{1}$ & 20.50 & 21.8 \\
\hline 2 & $\mathrm{~S}_{1} \mathrm{C}_{1} \mathrm{~L}_{2}$ & 18.81 & 19.9 \\
\hline 3 & $\mathrm{~S}_{1} \mathrm{C}_{2} \mathrm{~L}_{1}$ & 21.77 & 22.3 \\
\hline 4 & $\mathrm{~S}_{1} \mathrm{C}_{2} \mathrm{~L}_{2}$ & 21.75 & 21.8 \\
\hline 5 & $\mathrm{~S}_{2} \mathrm{C}_{1} \mathrm{~L}_{1}$ & 20.93 & 22.8 \\
\hline 6 & $\mathrm{~S}_{2} \mathrm{C}_{1} \mathrm{~L}_{2}$ & 17.39 & 18.4 \\
\hline 7 & $\mathrm{~S}_{2} \mathrm{C}_{2} \mathrm{~L}_{1}$ & 20.81 & 20.4 \\
\hline 8 & $\mathrm{~S}_{2} \mathrm{C}_{2} \mathrm{~L}_{2}$ & 20.03 & 22.3 \\
\hline 9 & $\mathrm{~S}_{3} \mathrm{C}_{1} \mathrm{~L}_{1}$ & 19.02 & 18.4 \\
\hline 10 & $\mathrm{~S}_{3} \mathrm{C}_{1} \mathrm{~L}_{2}$ & 16.10 & 15.9 \\
\hline 11 & $\mathrm{~S}_{3} \mathrm{C}_{2} \mathrm{~L}_{1}$ & 18.32 & 17.0 \\
\hline 12 & $\mathrm{~S}_{3} \mathrm{C}_{2} \mathrm{~L}_{2}$ & 18.87 & 19.4 \\
\hline
\end{tabular}

\section{Cellulose}

The results (Table 1) on cellulose content of substrates (decreased with advancement of incubation period. Initial cellulose content in $\mathrm{S}_{1}$ (sugarcane trash), $\mathrm{S}_{2}$ (paddy straw) and $\mathrm{S}_{3}$ (banana pseudostem) was 40.7, 37.8 and 48.8 per cent, respectively and decreased at 120 days of incubation to $32.7,32.2$ and 38.3 per cent, respectively. Rate of degradation of banana pseudostem cellulose was faster $\left(\mathrm{t}_{50}\right.$ : 275 days) than paddy straw ( $\mathrm{t}_{50}: 394$ days) and sugarcane trash ( $\mathrm{t}_{50}: 304$ days) might be due to narrower $\mathrm{C}$ : $\mathrm{N}$ ratio in banana pseudostem. These results are in conformity with results of Chang and Holtzapple (2000).

Cellulolytic isolate $\mathrm{C}_{1}$ achieved the higher cellulose reduction of the substrates than cellulolytic isolate $\mathrm{C}_{2}$. Among the lignolytic isolates, isolate $\mathrm{L}_{2}$ degrade more cellulose from the substrates.

Higher cellulose reduction under these treatments might be due to higher enzyme production by cellulolytic isolate $\mathrm{C}_{1}$ and lignolytic isolate $\mathrm{L}_{2}$. The results obtained from this experiment also agreeing with the results of Cortz et al., (1996).

\section{Lignin}

Substrates were varied in their lignin content and lower lignin content was found in the substrate $\mathrm{S}_{2}$ (paddy straw) as compared with other two substrates (Table 1).

Degradation of crop residues starts with easily degradable plant constituents and degrade in following order sugar and starch $>$ protein $>$ fat $>$ cellulose $>$ hemicellulose $>$ lignin.

Degradation of lignin is very slow therefore, lignin gets concentrated at initial stage of decomposition, than stabilized and decrease its content at later stage of decomposition. Similar results also reported by Tian et al., (1992).

Among the cellulolytic and lignolytic isolates, lignolytic isolate $\mathrm{L}_{2}$ was found to decrease the lignin content significantly at 120 days incubation.

However, both $\mathrm{L}_{1}$ and $\mathrm{L}_{2}$ remained at par with respect to lignin degradation. Higher lignin degradation under lignolytic isolate treatments might be due to production of lignolytic enzymes by the lignolytic isolates. 


\section{Regression study}

Decomposition rate is depends on composition of crop residues such as $\mathrm{C}$ : $\mathrm{N}$ and $\mathrm{C}: \mathrm{P}$ ratio, lignin and cellulose content of the residues. Considering all these important parameters, several regression equations were derived (Table 3). Amongst the regression equations, equation $\mathrm{W}=12.67+0.24 \mathrm{C}: \mathrm{N}+0.12$ L-0.06 CL gave maximum $\mathrm{R}^{2}(0.59)$. This indicates that $\mathrm{C}: \mathrm{N}$ ratio, lignin and cellulose content of the substrates play a important role in determining the rate of degradation. The values of these biochemical parameters observed at 120 days in different treatment combination were put in this best fitted regression equation. The comparatively lower predicted weight of $16.1 \mathrm{~g}$ was observed in treatments of $\mathrm{S}_{3} \mathrm{C}_{1} \mathrm{~L}_{2}$, followed by $\mathrm{S}_{2} \mathrm{C}_{1} \mathrm{~L}_{2}$ (17.4g) and $\mathrm{S}_{3} \mathrm{C}_{2} \mathrm{~L}_{1}$ (18.3g) (Table 5). The results of present study are taking to those reported earlier by Pangga et al., (2000).

\section{Identification of bacteria}

Based on sequence homology bacteria were identified as $\mathrm{C}_{1}$ as Bacillus licheniformis strain $\mathrm{C}_{1}$ and $\mathrm{L}_{2}$ as Bacillus sp. strain $\mathrm{L}_{2}$. Sequences were submitted to GenBank for accession number.

Total 103 bacterial strains were isolated from different sources viz., soil, sea water and manure. Finally, two most potent cellulolytic $\left(\mathrm{C}_{1}\right.$ and $\left.\mathrm{C}_{2}\right)$ and lignolytic $\left(\mathrm{L}_{1}\right.$ and $\left.\mathrm{L}_{2}\right)$ bacteria were selected from these isolates for manure preparation study by conducting qualitative and quantitative cellulase, laccase, lignin peroxidase and manganese peroxidase enzymes. The manure prepared by inoculating banana pseudostem with cellulolytic isolate $\mathrm{C}_{1}$ and lignolytic isolate $\mathrm{L}_{2}$ provide manure with acceptable quality in terms of $\mathrm{C}$ : $\mathrm{N}$ ratio and biochemical composition. Both cellulolytic $\left(\mathrm{C}_{1}\right)$ and lignolytic $\left(\mathrm{L}_{2}\right)$ bacterial isolates were identified as Bacillus lichenformis strain $\mathrm{C}_{1}$ and Bacillus sp. strain $\mathrm{L}_{2}$, respectively by $16 \mathrm{~S}$ rDNA gene identification technique for further studies.

\section{Acknowledgement}

I acknowledge Directorate of Science and Technology (DST), Government of India for providing INSPIRE (Innovation in Science Pursuit for Inspired Research) fellowship as a financial support to accomplish this experiment.

\section{References}

APHA (1984). Compendium of Methods for the Microbiological Examination of Foods, 2nd ed. APHA, Washington, DC.

Ball, A., Betts, W. and McCarthy, A. (1989). Screening Actinomycetes for extracellular Peroxidase Activity. Appl. Environmental Microbiol., 55: 16421644.

Becking, J. (2006). The family Azotobacteraceae. Prokaryotes. 6: 759783

Chang, V. S. and Holtzapple, M. T. (2000). Fundamental factors affecting biomass enzymatic reactivity. Appl Biochem Biotechnol, 84-86: 5-37.

Cortz, J., Demard, J. M., Bottner, T. and Joctur, M. M. L. (1996). Decomposition of Mediterranean leaf litter, micro cosmos experiment investigating relationship between decomposition rate litter quality. Soil Biology and Biochemistry, 28(4/5): 433-452.

Das, A. and Patel, G. G. (2011). Conversion of farm wastes/by-products in to enriched compost through use of microbial consortium. An Asian Journal of Soil science, 6 (2): 195-199.

Denise B. M., Maria L. A., Elba B., Julio S. A. N. and Sergio H. K. (1996). Colorimetric assay for lignin peroxidase 
activity determination using methylene blue as substrate. Biotechnological Techniques, 10(4): 273-276.

Gaur, A. C. (1999). Microbial technology for composting of agricultural residues by improved methods. Indian Council of Agricultural Research, New Delhi, pp:34-36.

Golueke, C. (1991). The art and science of composting. The Staff of BioCycle Journal of Waste Recycling, pp:14-27.

Jackson, M. L. (1973). Soil Chemical Analysis. Prentice-Hall of India Pvt. Ltd., New Delhi.

Miller, G.L. (1959). Use of Dinitrosalicylic Acid Reagent for Determination of Reducing Sugar. Anal. Chem., 31:426428.

Pangga, G. V., Blair, G. and Lefroy, R. (2000).Measurement of decomposition and associated nutrient release from straw (Oryza sativa L.) of different rice varieties using a perfusion system. Plant and Soil, 223: 1-11.

Panse, V. G. and Sukhatme, P.V. (1967). Statistical methods for agricultural workers. ICAR, New Delhi, India.

Papinutti, L., and Martinez, J. M. (2006). Production and characterization of laccase and manganese peroxidase from the ligninolytic fungus Fomes sclerodermeus. Journal of technology and biotechnology, 81:1064-1070.

Paterson, R. R. M. and Bridge, P. D. (1994). Biochemical techniques for filamentous fungi. CAB International, London, UK. Sadasivam, S. and Manickam, A. (1992) Biochemical methods for agricultural sciences. Wiley Eastern Ltd., New Delhi.pp: 62-63.

Singh, S. and Nain, L. (2014). Microorganisms in the conversion of agricultural wastes to compost. Proc. Indian Natn Sci. Acad., 80(2): 473-481.

Singh, Y. and Sidhu, H. S. (2014).Management of cereal crop residues for sustainable rice-wheat production system in the Indo-Gangetic Plains of India. Proc Indian NatnSci Acad., 80: 95-114.

Stafford, H. A. (1960). Differences between lignin-like polymers formed by peroxidation of eugenol and ferulic acid in leaf sections of Phleleum. Plant Physiol., 35: 108-114.

Thurston, C. F. (1994). The structure and function of fungal laccases. Microbiology, 140: 19-26.

Tian, G., Kang, B. T. and Brussaard, L. (1992). Effects of chemical composition of $\mathrm{N}, \mathrm{Ca}$ and $\mathrm{Mg}$ release during incubation of leaves from selected agroforestry and fallow plant species. Biogeochemistry, 16: 103-119.

Wolfenden, B. S. and Wilson, R. I. (1982). Radical cations as reference chromogens in kinetic studies of one electron transfer reactions. J. Chem. Soc. Perkin., 11:805-812.

\section{How to cite this article:}

Neethu, T.M., K.G. Patel, Singh Susheel and Sree Ganesh S. 2017. Assessment of Manure Quality Prepared From Different Crop Residues Inoculated with Cellulolytic and Lignolytic Bacterial Isolates. Int.J.Curr.Microbiol.App.Sci. 6(11): 1653-1661. doi: https://doi.org/10.20546/ijcmas.2017.611.198 